\title{
Calretinin expression as a risk biomarker for metastatic canine mammary carcinoma
}

\author{
Omid Dezfoulian ${ }^{1 *}$, Hesameddin Akbarein², Shahram Jamshidi ${ }^{3}$ Hananeh Golshahi', \\ Hamed M. Lakooraj ${ }^{5}$, and Leila Haghighi6 \\ ${ }^{1}$ Department of Pathology, School of Veterinary Medicine, Lorestan University, Khorram Abad, Iran \\ ${ }^{2}$ Department of Epidemiology, Faculty of Veterinary Medicine, University of Tehran, Tehran, Iran \\ ${ }^{3}$ Department of Clinical Sciences, Faculty of Veterinary Medicine, Tehran, Iran \\ ${ }^{4}$ Nanobiotechnology Research Center, Avicenna Research Institute, ACECR, Tehran, Iran \\ ${ }^{5}$ Malard City Veterinary Office, Department of Veterinary Diagnosis and Treatment, Alborz Province, Iran \\ ${ }^{6}$ Baqiyatallah Hospital, Tehran, Iran
}

DEZFOULIAN, O., H. AKBAREIN, S. JAMSHIDI, H. GOLSHAHI, H. M. LAKOORAJ, L. HAGHIGHI: Calretinin expression as a risk biomarker for metastatic canine mammary carcinoma. Vet. arhiv 90, 453-466, 2020.

\section{ABSTRACT}

Malignant breast tumors are the most common tumors in humans and are associated with a poor prognosis. An accurate animal model of human mammary gland tumorigenesis is needed to test novel diagnosis and treatment strategies. Dogs represent a promising model since they develop such tumors spontaneously. In the present study, three immunomarkers, including calretinin, c-Kit (CD117) and placental alkaline phosphatase (Plap), were used and compared with each other, in relation to estrogen and progesterone receptors and HER2 (triple markers), with the intention of malignancy grading. Enhanced expression of calretinin and placental alkaline phosphatase, without immunoreaction to c-Kit in neoplastic cells, is related to high-grade malignancy. Out of 50 tumors, 31 were metastasized, 29 of which $(93.5 \%)$ were moderately to strongly calretinin positive $(\mathrm{P}<0.05)$. However, the results for c-Kit - and Plap+ in metastatic tumors were not reproducible. It may be concluded that calretinin could be introduced as a determinant biomarker in the diagnosis of breast cancer metastasis.

Key words: biomarker; canine breast cancer; calretinin; c-kit; placenta alkaline phosphatase

\section{Introduction}

It has been well established that estrogen receptor (ER) expression, along with progesterone receptor (PR) and epidermal growth factor receptor 2 (HER2), which are known as the triple markers, are prognostic and predictive in evaluation and management of malignant canine mammary tumors (CMTs) and human breast cancer (ONITIL et al., 2009).

\footnotetext{
*Corresponding author:

Omid Dezfoulian, Department of Pathology, School of Veterinary Medicine, Lorestan University, Khorram Abad, Iran, Khorram Abad, Iran, E-mail: omidvete@yahoo.com; dezfoulian.o@lu.ac.ir
} 
Nevertheless, some tumors have no response to any of these immunohistochemical markers, and therefore, employing other markers to unveil concealed cancer profiles is unavoidable (TALIANO et al., 2013).

In light of recent studies, many biomarkers have frequently been used to assess the tumor-grading score as a novel standard.

In the present research, three immunomarkers, including c-Kit (CD117), calretinin, and placental alkaline phosphatase (Plap) were used on tissue samples, to be compared with the triple markers that may be considered as practical tools in delineation of cutoff values between normal, benign, and malignant conditions.

With functions including proliferation, migration, and survival of hematopoietic stem cells, melanoblasts, primordial germ cells, endothelial, epithelial and endocrine cells, c-Kit proto-oncogene may be expressed in different tissues. It is postulated that the c-Kit gene plays a mysterious role in several diseases, with gain-of-function mutations including mastocytoma, gastrointestinal stromal tumors, and glial tumors, besides the loss of function and mutations associated with breast cancer (BERNEX et al., 1996; MAFFINI et al., 2008; MAHZOUNI and JAFARI, 2012).

Calretinin is a $29-\mathrm{KD}$ calcium binding protein, primarily expressed in neuronal cells. However, it can be tracked in other normal or neoplastic cells (LUGLI et al., 2003; ROGERS 1987; TALIANO et al., 2013). The main application of this protein is to distinguish mesothelioma from poorly differentiated pulmonary adenocarcinomas, but this marker may also be expressed in other malignant tumors affecting ovaries, testes, adrenal glands, the colon, breasts, the thymus, skin, and soft tissue (LUGLI et al., 2003; POWELL et al., 2011; TALIANO et al., 2013).

Located in certain polarized epithelial cell types, placental alkaline phosphatases are glycosyl phosphatidylinositol-lipid anchored membrane proteins, with wide substrate specificity (FISHMAN 1987, HARRIS 1990), producing an organic radical and inorganic phosphate in an alkaline medium as a catalyzer, by hydrolysis of phosphate esters (REICHLING and KAPLAN, 1988). Several isoenzymes of ALP are detected in specific organs. These enzymes are derived from the liver, bones, kidneys, placenta, intestines, and leukocytes (FRIEDMAN et al., 1996).

Diagnosis of a variety of diseases is related to serum ALP elevation, and it is a reliable and specific marker for some complications, including biliary cirrhosis, sclerosing cholangitis, hepatic lymphoma, breast cancer, and sarcoidosis (NEUSCHWANDER- TETRI, 1995).

Although remarkable achievements, such as molecular assays, are characterized as high standards for classification of breast cancer (for example, c-Kit is a receptor tyrosine kinase (RTK) encoded by the KIT gene, and its mutations have recently been evaluated (KOLTAI et al., 2018) or in an earlier study (KUBO et al., 1998), as traditional test), Immunohistochemistry (IHC) is more available and reliable than other methods (PARISE and CAGGIANO, 2014).

\section{Materials and methods}

Sample size. Fifty formalin fixed samples of primarily surgically excised malignant mammary tumors were collected from dogs, hospitalized at the Small Animal Teaching Hospital, University of Tehran, private veterinary hospitals and the veterinary clinic of Lorestan University. Of these, 31 tumors had metastasized to the regional lymph nodes or distant organs, as diagnosed by FNA, imaging techniques, surgery, and in necropsy findings (Table 1) and the malignancy of the remainder was confirmed according to histopathological profiles (therefore, all were grade 3). Moreover, 29 of the tissue specimens were identified as malignant (including 17 metastatic and 12 non-metastatic specimens) by the auxiliary method of MALDITOF, mass spectrometry prior to histopathological evaluation (ZAMANI-AHMADMAHMUDI et al., 2014).

Histopathology. The histopathological typing and grading of malignant neoplasms in the current research were carefully classified according to the new classification system proposed by GOLDSCHMIDT et al., 2011, depicted in Table 1. It is noteworthy that several cases were found to have two or more histological patterns. 
Table 1. Histopathological pattern and score staining of immunomarkers in patients

\begin{tabular}{|c|c|c|c|c|c|c|c|c|}
\hline No. & Pattern & Er & $\operatorname{Pr}$ & Her-2 & $\mathrm{Cal}$ & c-Kit & Plap & Metastasis \\
\hline 1 & $\begin{array}{l}\text { Papillary cystic }+ \text { ductal carcinoma }+ \\
\text { anaplastic carcinoma }\end{array}$ & 0 & 0 & 1 & 2 & 0 & 1 & LN, Liver \\
\hline 2 & Solid carcinoma & 0 & 0 & 0 & 2 & 0 & 2 & $\mathrm{LN}$ \\
\hline 3 & $\begin{array}{l}\text { Tubular - tubulopapillary + papillary } \\
\text { cystic carcinoma }\end{array}$ & 0 & 0 & 0 & 3 & 0 & 1 & $\mathrm{LN}$ \\
\hline 4 & Ductal carcinoma & 0 & 0 & 0 & 1 & 0 & 0 & ND \\
\hline 5 & Anaplastic carcinoma & 0 & 0 & 0 & 0 & 0 & 0 & - \\
\hline 6 & Complex carcinoma & 0 & 0 & 0 & 3 & 1 & 1 & Lung \\
\hline 7 & Tubular carcinoma & 0 & 0 & 0 & 2 & 0 & 0 & LN, Lung \\
\hline 8 & $\begin{array}{l}\text { Tubular carcinoma with interlobular } \\
\text { fibrosis }\end{array}$ & 0 & 0 & 0 & 2 & 0 & 0 & Lung, Spleen \\
\hline 9 & Tubular carcinoma & 0 & 0 & 0 & 2 & 0 & 0 & LN, Lung \\
\hline 10 & $\begin{array}{l}\text { Carcinoma and malignant } \\
\text { myoepithelioma }\end{array}$ & 0 & 0 & 2 & 2 & 1 & 2 & LN, Lung \\
\hline 11 & Tubular carcinoma & 0 & 0 & 0 & 1 & 0 & 0 & - \\
\hline 12 & $\begin{array}{l}\text { Carcinosarcoma }+ \text { carcinoma } \\
\text { and malignant epithelioma }+ \\
\text { inflammatory carcinoma }\end{array}$ & 1 & 0 & 0 & 3 & 1 & 0 & $\mathrm{LN}$ \\
\hline 13 & Tubulopapillary carcinoma & 0 & 0 & 1 & 1 & 0 & 0 & - \\
\hline 14 & Carcinoma in situ & 0 & 2 & 0 & 2 & 2 & 0 & - \\
\hline 15 & Solid carcinoma & 0 & 1 & 0 & 3 & 0 & 0 & $\mathrm{LN}$ \\
\hline 16 & Carcinosarcoma & 0 & 0 & 0 & 0 & 0 & 0 & $\mathrm{LN}$ \\
\hline 17 & $\begin{array}{l}\text { Tubulo - micropapillary, } \\
\text { intraductal carcinoma + lipid laden }\end{array}$ & 0 & 0 & 0 & 3 & 0 & 0 & LN, Lung \\
\hline 18 & Complex carcinoma & 0 & 0 & 0 & 0 & 0 & 0 & - \\
\hline 19 & Complex carcinoma & 0 & 0 & 0 & 3 & 0 & 0 & $\mathrm{LN}$ \\
\hline 20 & Complex carcinoma & 2 & 1 & 2 & 3 & 0 & 0 & Lung \\
\hline 21 & $\begin{array}{l}\text { Intraductal papillary carcinoma to } \\
\text { tubulopapillary carcinoma }\end{array}$ & 0 & 0 & 3 & 3 & 0 & 1 & Lung \\
\hline 22 & $\begin{array}{l}\text { Micropapillary carcinoma }+ \\
\text { intraductal papillary carcinoma }+ \\
\text { solid adenosquamous }\end{array}$ & 0 & 1 & 3 & 3 & 0 & 0 & LN, Lung \\
\hline 23 & Carcinosarcoma + tubular carcinoma & 2 & 0 & 3 & 3 & 0 & 1 & Liver \\
\hline 24 & Tubulopapillary +cribriform & 0 & 0 & 0 & 0 & 2 & 2 & ND \\
\hline 25 & Cribriform carcinoma & 0 & 0 & 0 & 3 & 1 & 0 & $\mathrm{LN}$ \\
\hline 26 & Solid carcinoma & 0 & 0 & 1 & 0 & 0 & 0 & - \\
\hline 27 & Tubular carcinoma & 0 & 0 & 0 & 2 & 0 & 1 & $\mathrm{LN}$ \\
\hline 28 & Intraductal carcinoma & 0 & 0 & 3 & 0 & 0 & 0 & - \\
\hline 29 & $\begin{array}{l}\text { Tubulopapillary carcinoma }+ \\
\text { anaplastic carcinoma }\end{array}$ & 3 & 0 & 2 & 2 & 1 & 1 & - \\
\hline 30 & Tubular carcinoma & 0 & 0 & 0 & 3 & 0 & 0 & LN \\
\hline 31 & Intraductal carcinoma & 0 & 0 & 0 & 0 & 0 & 2 & LN, Bone \\
\hline 32 & Carcinosarcoma & 0 & 0 & 2 & 1 & 0 & 0 & - \\
\hline
\end{tabular}


O. Dezfoulian et al.: Calretinin expression as a risk biomarker for metastatic canine mammary carcinoma

Table 1. Histopathological pattern and score staining of immunomarkers in patients (continued)

\begin{tabular}{|c|l|c|c|c|c|c|c|c|}
\hline No. & Pattern & Er & Pr & Her-2 & Cal & c-Kit & Plap & Metastasis \\
\hline 33 & Tubular carcinoma & 0 & 0 & 3 & 3 & 0 & 1 & Lung \\
\hline 34 & Tubular carcinoma & 0 & 0 & 0 & 1 & 2 & 2 & - \\
\hline 35 & Complex carcinoma & 0 & 0 & 0 & 1 & 0 & 0 & - \\
\hline 36 & Tubular carcinoma & 0 & 0 & 0 & 2 & 0 & 1 & LN, Lung \\
\hline 37 & Solid + intraductal carcinoma & 0 & 0 & 0 & 0 & 0 & 0 & - \\
\hline 38 & Solid + cribriform carcinoma & 2 & 3 & 2 & 0 & 0 & 2 & ND \\
\hline 39 & Tubular carcinoma & 0 & 0 & 3 & 2 & 2 & 1 & LN, Lung \\
\hline 40 & Complex carcinoma & 0 & 0 & 3 & 2 & 0 & 2 & LN \\
\hline 41 & Intraductal carcinoma & 0 & 0 & 2 & 1 & 0 & 0 & - \\
\hline 42 & Solid carcinoma & 2 & 2 & 3 & 0 & 0 & 1 & - \\
\hline 43 & Tubulopapillary carcinoma & 2 & 2 & 3 & 3 & 0 & 0 & LN, Lung \\
\hline 44 & Complex carcinoma & 2 & 0 & 3 & 3 & 0 & 1 & LN \\
\hline 45 & Complex carcinoma & 0 & 0 & 3 & 3 & 0 & 0 & LN \\
\hline 46 & Anaplastic carcinoma & 0 & 0 & 3 & 2 & 0 & 0 & Bone \\
\hline 47 & Tubular + Cribriform carcinoma & 0 & 0 & 3 & 3 & 0 & 1 & LN \\
\hline 48 & Tubulopapillary carcinoma & 0 & 0 & 3 & 3 & 2 & 0 & LN, Lung \\
\hline 49 & Tubulopapillary + Micropapillary & 0 & 0 & 3 & 1 & 2 & 2 & - \\
\hline 50 & Cribriform to comedocarcinoma & 0 & 0 & 3 & 1 & 3 & 1 & - \\
\hline
\end{tabular}

Er, estrogen; Pr, progesterone; Her-2, human epidermal growth factor receptor-2; Cal, calretinin; Plap, placental alkaline phosphatase; ND, not defined; LN, lymph node

Table 2. Antibody specifications and pattern of staining

\begin{tabular}{|l|c|c|c|c|}
\hline Antibody & Clone & Dilution & Time of incubation & Pattern of staining \\
\hline ER monoclonal & 1D5 & $1: 100$ & $80 \mathrm{~min}$ & Nuclear \\
\hline PR monoclonal & PgR 636 & $1: 100$ & $80 \mathrm{~min}$ & Muclear \\
\hline HER2 monoclonal & PN2A & $1: 100$ & overnight at $4{ }^{\circ} \mathrm{C}$ & 80 min \\
\hline c-Kit polyclonal & $\begin{array}{c}\text { A4502 } \\
\text { Catalog no }\end{array}$ & $1: 500$ & $\begin{array}{c}\text { Cytoplasmic with membranous } \\
\text { accentuation }\end{array}$ \\
\hline Calretinin monoclonal & DAK-Calret1 & $1: 50$ & overnight at $4{ }^{\circ} \mathrm{C}$ & Nuclear, cytoplasmic \\
\hline PLAP monoclonal & 8A9 & $1: 50$ & 80 min & Membranous cytoplasmic \\
\hline
\end{tabular}

Immunohistochemical procedure. Paraffinembedded blocks of each tumor were used to prepare $4 \mu \mathrm{m}$-thick consecutive sections. The sections were then deparaffinized in xylene and rehydrated. Endogenous peroxidase was blocked by immersion in $0.3 \% \mathrm{H} 2 \mathrm{O} 2$ for 20 minutes. For antigen retrieval, the slides were incubated with Tris-EDTA $(\mathrm{pH}=9)$ for 15 minutes in an oven. In the next step, the slides were covered by primary antibodies for ER (clone ID5, Dako, Glostrup, Denmark, Cat No. M7047) at a dilution of 1:100, PR (clone PgR 636; Dako;
M3569 1:100) HER2-pY-1248 (Phosphorylation site specific) (clone PN2A, Dako; 1:100), c-Kit (A4502, Dako; 1:500), Calretinin (clone DAKCalret1, Dako; M7245, 1:50) and Plap (clone 8A9, Dako; MA5-14064, 1:50) followed by incubation with a Dako REAL ${ }^{\text {TM }}$ EnVision Detection System K5007. All the slides were then covered by $0.05 \%$ diaminobenzidine dihydrocloride solution (DAB), used as a chromogen, for 10 minutes, at ambient temperature. Antibody specifications and staining patterns are presented in Table 2. 
O. Dezfoulian et al.: Calretinin expression as a risk biomarker for metastatic canine mammary carcinoma

Table 3. Histopathological pattern and score staining of immunomarkers in normal and benign mammary glands

\begin{tabular}{|c|l|c|c|c|c|c|c|}
\hline No & Pattern & Er & Pr & Her-2 & Cal & c-Kit & Plap \\
\hline 1 & Normal & 2 & 2 & 0 & 0 & 3 & 0 \\
\hline 2 & Normal & 2 & 1 & 0 & 0 & 3 & 0 \\
\hline 3 & Normal & 3 & 2 & 0 & 0 & 2 & 0 \\
\hline 4 & Normal & 2 & 0 & 0 & 0 & 2 & 0 \\
\hline 5 & Normal & 1 & 2 & 0 & 0 & 3 & 0 \\
\hline 6 & Solid adenoma & 0 & 0 & 2 & 1 & 1 & 0 \\
\hline 7 & Complex adenoma & 0 & 0 & 3 & 0 & 0 & 0 \\
\hline 8 & Lobular hyperplasia & 0 & 0 & 2 & 0 & 1 & 0 \\
\hline 9 & Fibroadenoma & 0 & 0 & 3 & 0 & 0 & 0 \\
\hline 10 & Benign mixed & 0 & 0 & 2 & 0 & 0 & 0 \\
\hline 11 & Lobular hyperplasia & 1 & 0 & 3 & 0 & 1 & 0 \\
\hline 12 & Ductal adenoma & 0 & 0 & 2 & 1 & 0 & 0 \\
\hline
\end{tabular}

Er, estrogen; Pr, progesterone; Her-2, human epidermal growth factor receptor-2; Cal, calretinin; Plap, placental alkaline phosphatase;

Control samples. Positive and negative controls were included whenever possible to monitor the correct performance of the processed tissues. Positive internal control samples were selected from tumor blocks containing normal and nonneoplastic tissue. The external positive control samples are depicted in Table 3. For negative controls, homologous nonimmune serum or buffer replaced the primary antibodies.

Scoring and statistical analysis. The scoring system was almost the same as the Quick score by PENA et al. (2014).

It was modified for the percentage of cells labeled (no labeling $=-/+$, labeling $\leq 10 \%=+, 10$ up to $50 \%=++$, and more than $50 \%=+++$ ), the score for intensity (absent $=-$, weak $=+$, moderate $=++$, and strong $=+++$ ). Only $2+$ and $3+$ for HER 2 overexpression were determined as criteria, and +1 was excluded on the basis of the description by ORDAS et al. (2007).

Statistical analyses were performed by SPSS Version 19.0. The data were described as absolute and relative frequencies. The data were analyzed by Chi-square and Fisher's exact test. A P-value $\leq 0.05$ was considered statistically significant.

\section{Results}

The results of immunohistochemical analysis are presented in Table 1. Nuclear immuno-staining of epithelial cells and to a lesser extent, in stromal cells, were shown for ER and PR in normal samples. HER2 had positive membranous immunolabeling in tumor cells.

Calretinin positive cells were shown in luminal type tumor structures as linear patterns, in which the immunolabled cells with both cytoplasmic and nuclear immunoexpression were located in the innermost layer adjacent to the basement membrane. However, few myoepithelial cells reacted to this marker (Fig. 1; A, B). Conversely, widespread intermingled staining of neoplastic cells in other tumor types did not follow the specified pattern (Fig. 1; C-F). Calretinin expression was negative in all normal and most benign breast tumors, and weakly expressed in the rest (Table 3). Diffuse and strong cytoplasmic immunostaining by c-Kit was observed in normal epithelium (Fig. 2; A, B), while focal cytoplasmic and membranous expression was defined in benign or malignant neoplastic cells. A similar staining pattern was also determined in tumor cells by Plap, with no positively stained cells in the control group (Fig. 3; A-D). 

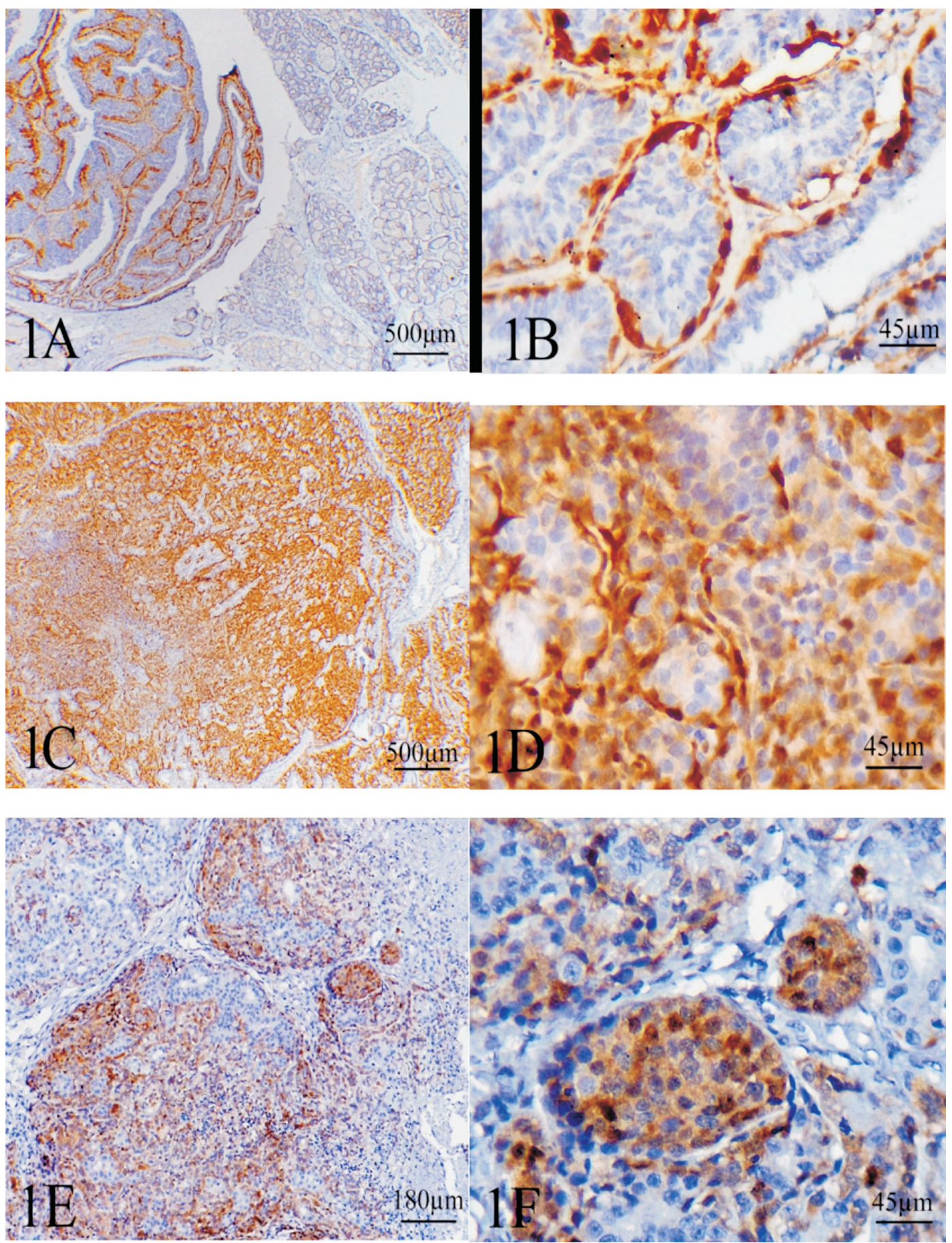

Fig. 1. Calretinin immunostaining. 1A - Tubular carcinoma, dog No. 23. Linear pattern; 1B - Higher magnification of Fig. 1A ; Nuclear and cytoplasmic immunopositive in epithelial neoplastic cells; 1C - Complex carcinoma,

dog No. 23. Diffuse immunostaining; 1D - Higher magnification of Fig. C. Both nuclear and cytoplasmic immunolabeling; 1E - Cribriform carcinoma, dog No. 25. Diffuse immunolabeling; 1F - Higher magnification of Fig.1 E. Both nuclear and cytoplasmic immunoexpression. 


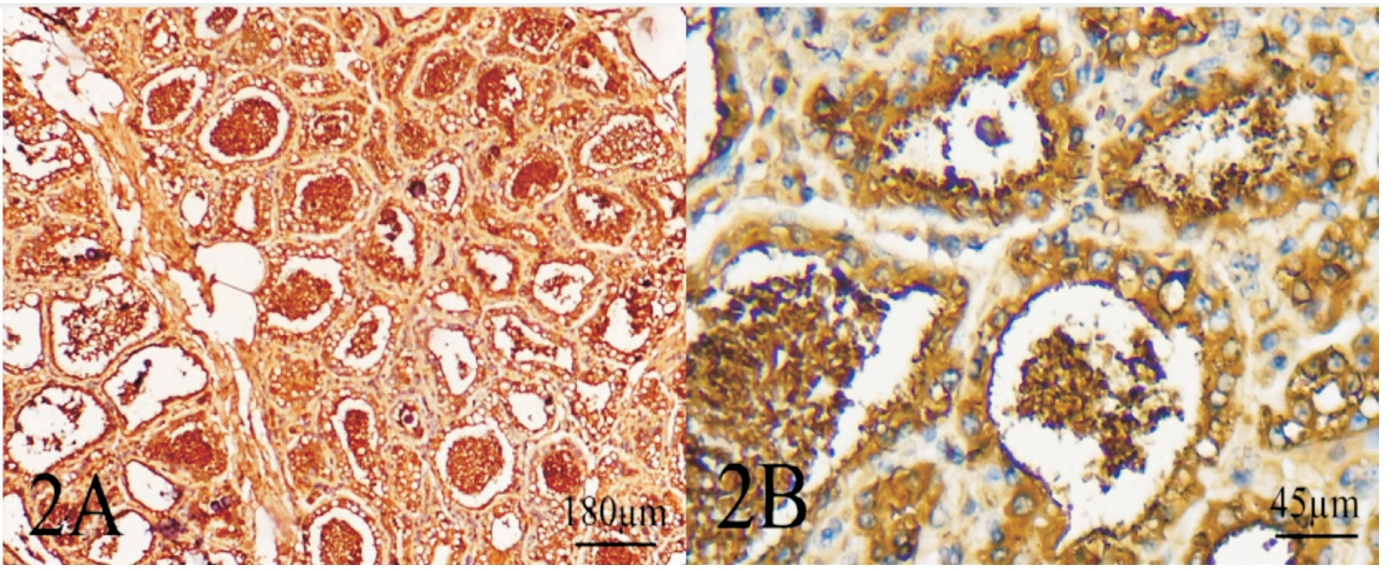

Fig. 2. c-Kit immunostaining. Control mammary gland; 2A - Diffuse cytoplasmic immunolabeling; 2B - Higher magnification of Fig. 2A.
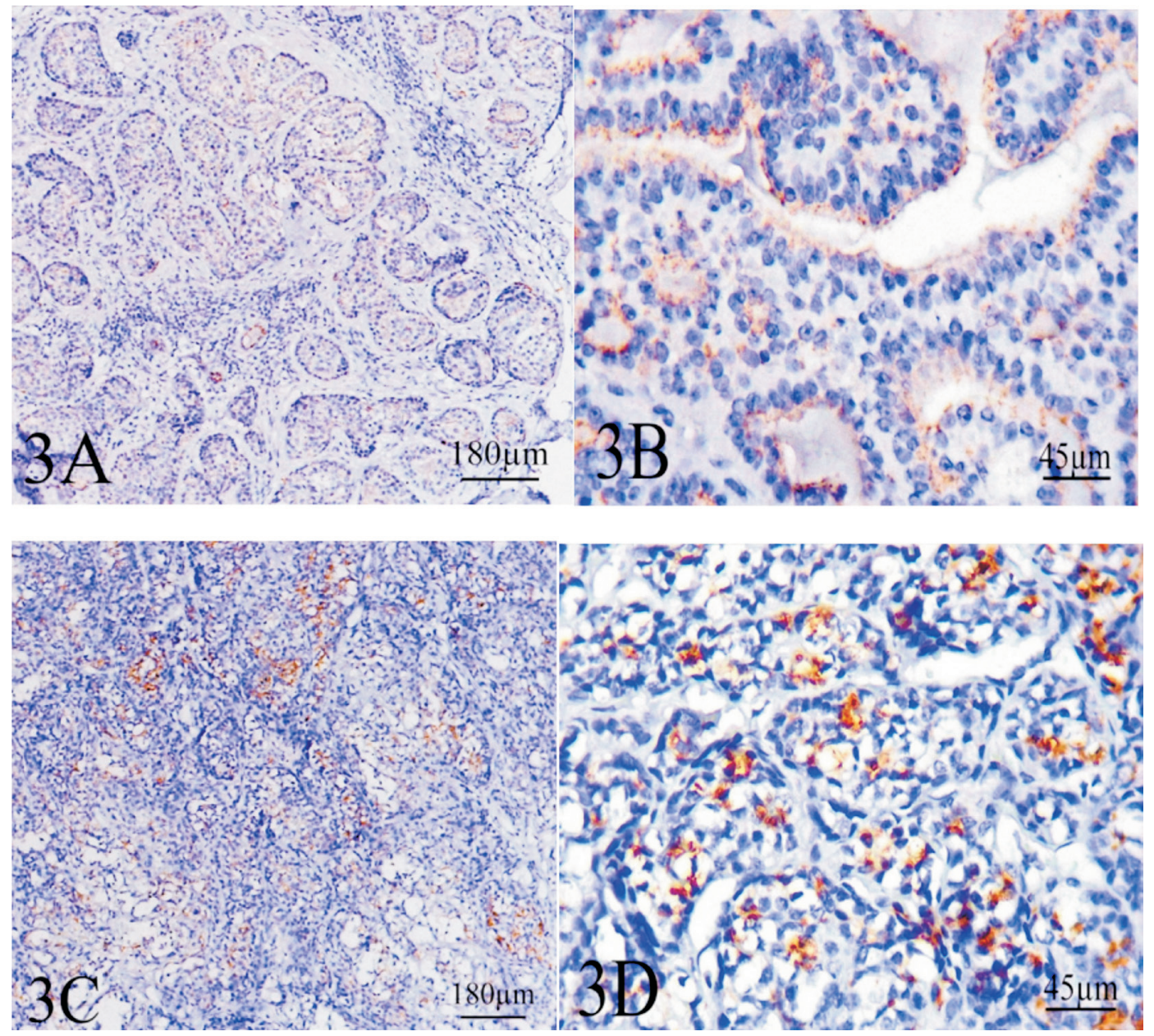

Fig. 3. Plap immunostaining. 3A - Cribriform-comedocarcinoma, dog No. 50. Cytoplasmic to membranous immuolabeling; 3B - Higher magnification of Fig. 3A; 3C - Solid carcinoma, dog No. 2; 3D. Higher magnification of Fig. 3C. 
The differences between calretinin $+/$ metastasis and calretinin + c-Kit -/Plap $+/$ metastasis were statistically significant $(\mathrm{P}<0.05)$; however, there were no statistical differences between ER-/ calretinin + /metastasis, c-Kit -/metastasis and Plap $+/$ metastasis $(\mathrm{P}>0.05)$.

Also, authentication of calretinin was employed in five canine metastasized tissue samples, including two regional lymph nodes (case no. 30 and 47), two pulmonary, and one liver specimen, in which the neoplastic cells responded as they did in mammary tumors.

Table 4 highlights the correlation of triple markers with calretinin, c-Kit, and Plap, as well as the possible contribution of each biomarker in malignant and metastatic breast cancers.

Table 4. Evaluation of immunohistochemical expression of triple markers, calretinin, c-Kit and Plap in metastatic patients

\begin{tabular}{|c|c|c|c|c|}
\hline \multicolumn{4}{|c|}{ Group } & \multirow{2}{*}{$\begin{array}{c}\text { Total } \\
5(16.1)\end{array}$} \\
\hline $\mathrm{ER}^{-} / \mathrm{PR}^{-} / \mathrm{HER} 2^{-}$ & $\mathrm{Cal}^{+}$ & ${\mathrm{c}-\mathrm{Kit}^{-}}^{-}$ & $\mathrm{PLAP}^{+}$ & \\
\hline ER-/PR-/HER2- & $\mathrm{Cal}^{+}$ & ${\mathrm{c}-\mathrm{Kit}^{+}}^{+}$ & $\mathrm{PLAP}^{+}$ & $1(3.2)$ \\
\hline $\mathrm{ER}^{-} / \mathrm{PR}^{-} / \mathrm{HER} 2^{-}$ & $\mathrm{Cal}^{+}$ & c-Kit ${ }^{-}$ & PLAP - & $6(19.3)$ \\
\hline ER $/$ PR $^{-} / \mathrm{HER}^{-}$ & $\mathrm{Cal}^{+}$ & ${\mathrm{c}-\mathrm{Kit}^{+}}^{+}$ & PLAP - & $2(6.4)$ \\
\hline ER-/PR-/HER2- & $\mathrm{Cal}^{-}$ & ${\mathrm{c}-\mathrm{Kit}^{-}}^{-}$ & PLAP - & $1(3.2)$ \\
\hline $\mathrm{ER}^{-} / \mathrm{PR}^{-} / \mathrm{HER} 2^{-}$ & $\mathrm{Cal}^{-}$ & c-Kit ${ }^{-}$ & $\mathrm{PLAP}^{+}$ & $1(3.2)$ \\
\hline ER-/PR-/HER2 $^{+}$ & $\mathrm{Cal}^{+}$ & ${\mathrm{c}-\mathrm{Kit}^{+}}^{+}$ & $\mathrm{PLAP}^{+}$ & $2(6.4)$ \\
\hline ER-/PR-/HER2 $^{+}$ & $\mathrm{Cal}^{+}$ & ${\mathrm{c}-\mathrm{Kit}^{-}}^{-}$ & $\mathrm{PLAP}^{+}$ & $4(12.9)$ \\
\hline ER-/PR-/HER2 ${ }^{+}$ & $\mathrm{Cal}^{+}$ & ${\mathrm{c}-\mathrm{Kit}^{-}}^{-}$ & PLAP - & $2(6.4)$ \\
\hline ER-/PR + /HER2- & $\mathrm{Cal}^{+}$ & $\mathrm{c}-\mathrm{Kit}^{-}$ & PLAP - & $1(3.2)$ \\
\hline $\mathrm{ER}^{-} / \mathrm{PR}^{+} / \mathrm{HER}^{+}{ }^{+}$ & $\mathrm{Cal}^{+}$ & $\mathrm{c}-\mathrm{Kit}^{-}$ & PLAP - & $1(3.2)$ \\
\hline $\mathrm{ER}^{+} / \mathrm{PR}^{+} / \mathrm{HER}^{+}$ & $\mathrm{Cal}^{+}$ & $\mathrm{c}-\mathrm{Kit}^{-}$ & PLAP - & $2(6.4)$ \\
\hline $\mathrm{ER}^{+} / \mathrm{PR}^{-} / \mathrm{HER} 2^{-}$ & $\mathrm{Cal}^{+}$ & ${\mathrm{c}-\mathrm{Kit}^{+}}^{+}$ & PLAP - & $1(3.2)$ \\
\hline \multirow[t]{2}{*}{$\mathrm{ER}^{+} / \mathrm{PR}^{-} / \mathrm{HER} 2^{+}$} & $\mathrm{Cal}^{+}$ & c-Kit ${ }^{-}$ & $\mathrm{PLAP}^{+}$ & $2(6.4)$ \\
\hline & & & & $31(100)$ \\
\hline
\end{tabular}

With regard to Table 5, it may be understood that the highest number of metastases were in the groups of triple negative 16/31 (51.6\%) and ER-/ PR-, HER2 ${ }^{+}$8/31 (25.8\%).
Table 5. The different states of triple markers (ER, PR, and HER2) and their correlation with calretinin in mammary gland metastases

\begin{tabular}{|l|c|c|c|}
\hline Triple groups & $\mathrm{Cal}^{+}$ & $\mathrm{Cal}^{-}$ & Total \\
\hline ER$/$ PR-/HER2- $^{-}$ & $14(45.1)$ & $2(6.45)$ & $16(51.6)$ \\
\hline ER-/PR-/HER2 $^{+}$ & $8(25.8)$ & $0(0)$ & $8(25.8)$ \\
\hline Others & $7(22.5)$ & $0(0)$ & $7(22.5)$ \\
\hline Total & $29(93.5)$ & $2(6.45)$ & $31(100)$ \\
\hline
\end{tabular}

\section{Discussion}

Alongside using triple markers, it might be necessary to optimize the exploitation of other markers in screening for and diagnosing breast cancer.

Recently, tumor markers have been developed in breast cancer research, due to their impact on prognosis, treatment, survival, and for their relationship to breast cancer subtypes (BAUER et al., 2007).

Determination of both ER and HER2 status in breast cancer is useful as prognostic and predictive factors, and this has become standard practice in the management of breast tumor (BAUER et al., 2007). HER 2 positivity has a direct link with aggressive tumor behaviors (PENA et al., 2014), while PR is only prognostic (HEFTI et al., 2013). The importance of canine HER2 overexpression in breast tumors remains unclear; although some researchers believe that in dogs too HER2 expression provides malignant conditions in breast tissue, but the average rate of its expression is a little above $30 \%$ in malignant tumors, and therefore it is not recognized as a reliable marker (AHREN et al., 1996; PENA et al., 2014). As shown in Table 2, apart from normal breast tissues that were HER2 negative, all benign tumors were moderately to strongly HER2 positive. RUNGSIPIPAT et al. (1999) in their study showed that compared to $19.1 \%$ of malignant tumors, half of 32 benign tumors were HER2 positive, therefore, its expression is higher in benign lesions than in malignant ones. Thus, a lower expression rate of HER2 is more probably associated with an unfavorable prognosis. 
The results from medical literature studies reveal that unlike in humans, hormone receptor levels are significantly lower in canine breast cancer, meaning that hormone independency is more apparent in dogs (RICKETTS et al., 1991; RUTTEMAN et al., 1988). It was concluded that canine ER and PR positivity were regularly lower than in normal breast tissue or benign lesions (RUTTEMAN et al., 1988). Therefore, it seems that elevation of ER and PR is directly related to pathological cell proliferation, and the expression of ER in normal human breast is favorable to breast cancer development (RICKETTS et al., 1991). Nevertheless, whereas in normal breast tissue and benign tumors, they are constant, in malignancy, canine ER and PR levels vary and tend to fall (RICKETTS et al., 1991; RUTTEMAN et al., 1988). While the expression of ER and PR in our normal dogs were consistent with literature, however lack of expressions were in conflict in benign tumors except one (case No.11, Table 3).

$\mathrm{PR}$ receptor expression takes place in almost two-thirds of carcinomas (CHANG et al., 2009; GERALDS et al., 2000; GUIL-LUNA et al., 2014; MARTIN de LAS MULAS et al., 2005), where a simple epithelial-type carcinoma, with the lowest levels of expression, this sticking point covers all benign tumors (GUIL-LUNA et al., 2014).

Simple epithelial-type carcinomas display less insensible PR expression compared to complex or mixed subtypes, and there is an association between PR expression and malignancy of tumors (GUIL-LUNA et al., 2014; MILLANTA et al., 2005). As in our results, PR was not expressed in most exclusively ER- $(38 / 50 ; 76 \%)$ lesions defined as having worse prognosis; however, all these are unlike the lowest expression of PR in experiments even in well-differentiated tumors (MOUSER et al., 2010).

However, for more accurate determination of prognosis and survival rate, usually both ER/PR and triple markers have been sporadically analyzed together, as follows: $\mathrm{ER}+\mathrm{PR}+$ breast cancers have the best prognosis, meanwhile patients with $\mathrm{ER}+/$ PR- display a worse clinical condition and more aggressive subtypes of ER+ breast cancers (HEFTI et al., 2013). The ER-/PR- subtype is the worst in terms of its response to conventional drugs. There is verified documentary evidence that PR is controlled by ER; therefore, ER- is a measure for PR-. Furthermore, PR expression has no logical connection with ER in the prognosis of breast cancers, and most authors believe that ER-/PR+ is a false subtype, although it remains controversial (HEFTI etal., 2013). ER-/PR+, in different literature, accounts for between zero and seven percent of breast cancer (BARDOU et al., 2003; COLDITZ et al., 2004; DE MAEYER et al., 2008; HEFTI et al., 2013; NADJI et al., 2005). It must be counted as a distinct subtype, showing clinicopathological signs, and so has worse prognosis than both ER+/ $\mathrm{PR}+$ and ER+/PR-, but better than an ER-/PRpatient. Nevertheless, the contingency of clinical signs is more similar to ER+ than ER-/PR- (CHAN et al., 2015; DE MAEYER et al. 2008; SHEN et al., 2015). However, $3 / 50$ (6\%) of our tumors appeared as ER-/PR+, all of which were Calretinin positive, and although the PR stained weakly, we could not rule these out as an artifact after a repeated test for both ER and PR, which had the same results. Perhaps, as in humans, it meant that the dogs were juvenile or had a higher tumor grade profile (CHAN et al., 2015; DE MAEYER et al., 2008).

If breast cancers are classified according to the triple markers, they provide valuable evidence for treatment policy. As a standard source, ER+/ $\mathrm{PR}+$, HER2- is the most prevalent subtype, ER+/ $\mathrm{PR}+$; HER2+ has good prognosis, while, both ER/ PR-, HER2+ and triple negative (ER/PR-, HER2-) usually have a poor response to chemo-drugs, with a reduction in life expectancy (ONITIL et al., 2009).

Although calretinin is a particular biomarker of mesothelial cells broadly employed for malignant mesothelioma recognition, its expression is demonstrated in carcinomas, such as malignant breast tumors and sarcomas (LUGLI et al., 2003; TALIANO et al., 2013). Lung, salivary gland, ovary, stomach, and colon carcinomas have been studied for this marker (POWELL et al., 2011). Moreover, calretinin is a promising candidate for testicular tumor diagnosis (CAO et al., 2001).

In veterinary literature, this marker has been applied in normal and neoplastic canine testicles. Only leydig and sertoli cells reacted to calretinin in 
normal testis; however, its expression was revealed in all varieties of testicular tumors on the basis of the priority order, including leydig cell tumor, seminoma, and sertoli cell tumor (CIAPUTA et al., 2014; RADI and MILLER 2005).

Canine oral lesions such as acanthomatous ameloblastoma (CAA) and oral squamous cell carcinoma (OSCC) has also been tested with calretinin, with a significant reaction of the OSCC (FULTON et al., 2014).

A strong correlation between calretinin expression and metastasis was found first in this study $(\mathrm{P}<0.05)$. It is anticipated that calretinin plays an important role in epithelial- mesenchymal transition (EMT); therefore, with vimentin expression, these markers might be considered as metastatic potentiation indicators (HENNESSY et al., 2009; TALIANO et al., 2013; ZHANG et al., 2012).

Well-differentiated and individual ER+ tumors are generally calretinin negative, and, conversely, tumors with stronger calretinin expression are high grade. ER- is often associated with poor prognosis (LUGLI et al., 2003; POWELL et al., 2011; TALIANO et al., 2013).

Currently, only a few sources are available in the veterinary literature about the role of Plap and its diagnostic value in diseases. For example, its elevation was noticed as a good indicator in some canine conditions such as hepatic and endocrine diseases, and osteopathy (MILNE 1985), but it has not been fully investigated in neoplasms.

The expression of placental alkaline phosphatase was directly associated with some types of cancers in human (CHANG et al., 1994; FISHMAN 1987; LANGE et al., 1982) and its function was induced by progestin in ER+ breast cancer cell lines, and by estrogen in endometrial adenocarcinoma cells (CHANG et al., 2009; DI LORENZO et al., 1993; DI LORENZO et al., 1991). Our results in this context are significantly different. According to Table 1 , only $2 / 22(9 \%)$ of cases followed this pattern (ER+/PR+ Plap + ) and 3/22 (13.6\%) were (ER+/PR- Plap+) while 17/22 (77\%) were (ER-/ PR- Plap + ) and Plap function might be affected by other factors apart from ER/PR. The production of this tumor marker is associated with an oncodevelopmental gene, sometimes detectable in low levels of normal human serum, but excessive expression is indicative of cancer (MOSSNER et al., 1984). In accordance with the literature data, Plap expression is demonstrated in $20 \%$ of breast carcinomas $(22 / 50$ [44\%] in present data) and in $75 \%$ of intestinal carcinomas, and is not traceable in normal breast tissue or benign tumors (MOSSNER et al., 1984).

Therefore, Plap might be considered a potential biomarker in the diagnosis of malignant breast tumors, exclusively on fixed tissue sections using the immunohistochemical method (MCDICKEN et al., 1983; MOSSNER et al., 1984; STIGBRAND et al., 1985).

Plap was not recognized in this study in either normal or benign tumors, although it appeared in 22 malignant cases, 15 of which were metastasized. Similar to others, it is not beyond possibility that Plap induction has a direct link with malignancy.

In normal epithelial breast cells, the c-Kit receptor is located in large amounts on the membrane or cytoplasm of ductal or alveolar structures (CHUI et al., 1996; MAFFINI et al., 2008), but with cellular proliferation in benign lesions, its amount is impressively reduced and it is absolutely unrecognizable in poorly differentiated cells (MAFFINI et al., 2008; NATALI et al., 1992; ULIVI et al., 2004). As shown in Table 2, our results are fully in line with those of other researchers. C-Kit was decisively expressed in normal breast tissues and gradually reduced or completely absent in benign tumors. The evidence indicates that homoeostasis regulation and differentiation of normal mammary epithelial cells are taken up by c-Kit in a complex molecular network, and it achieves second place in maintenance of normal growth in glandular epithelial cells after $\beta 1$ integrin (REGAN et al., 2012). Therefore, in the absence of c-Kit, malignancy process could develop (MAFFINI et al., 2008; NATALI et al., 1992). One of the original mechanisms that contributes to c-Kit receptor loss in normal cells and subsequently accumulation of malignancy characteristics, is probably related to tyrosine kinase inhibitors and 
the reduction in c-Kit activity (MAFFINI et al., 2008; SAMOSZUK and CORWIN 2003).

Surprisingly, in their study on canine breast cancer using real-time RT-PCR, KOLTAI et al. (2018) found that c-Kit mutation occurred in 13 dogs with mammary gland carcinoma, measured with other tyrosine kinases markers (including; VEGF, VEGFR1, PDGFR1, EGFR and c-MET), and concluded that mRNA expression of c-Kit was significantly higher than in normal breasts. In a similar work on 11 dogs, c-Kit RT-PCR product was higher in all benign and malignant carcinomas; however, its expression was low in normal glands (KUBO et al., 1998).

This is inconsistent with the present study and other results. The discrepancy might be related to the methodology. For example, ULIVI et al. (2004) studied c-Kit and its ligand

(SCF) in normal cells, in situ, and invasive breast cancers using immunohistochemistry for c-kit and SCF protein, and an in situ hybridization technique, as well as RT-PCR for mRNA expression.

Both protein and mRNA expression of c-Kit and SCF were high in normal glands, lower in in situ, and absent in invasive breast cancer in IHC and in situ hybridization. However, by RT-PCR mRNA expression, they were displayed in both normal and breast tumors.

The authors believed that the variable results were due to the application of different methodologies, and concluded that morphological methods are the most reliable and applicable for detection of c-Kit and SCF in normal and tumor cells. In another study, c-Kit was evaluated in normal, nonmetastatic, and metastatic breast cancer on the basis of its pattern as precursor of canine mast cell tumor (MCT) (SALVADOR et al., 2013). The results were unexpected and not in accordance with the (MCT) profile pattern. However, they had not pointed out score and the protein was expressed in all samples.

In our results, $30.7 \%$ and $50 \%$ of normal internal glands were calretinin positive in those tumors with +2 and +3 intensity scoring, respectively $(p=0.3)$ using the independent $t$-test. It was $37.5 \%$ for Plap with intensity 2 and 100\% negative for c-Kit, and score zero. Perhaps this means that upregulation of calretinin and Plap in some normal glands precedes or is concurrent with its expression in neoplastic epithelial cells, whereas gene knockout is uniformed in both normal and neoplastic cells for c-Kit. Therefore, it must be assumed that it is inappropriate to consider normal glands alongside malignant structures as an internal control, and for proper evaluation, we strongly recommend using normal external controls.

\section{Conclusion}

Calretinin could be very useful alone or in conjunction with ER, PR, and HER2 antibodies in identifying and prognosis of malignant mammary gland tumors, from normal or benign lesions. However, another marker such as c-Kit and Plap can also play a potential role in defining such differences. Although the ER- was not significant in metastatic tumors, it must still be considered that $24 / 31$ of metastatic tumors $(77.4 \%)$ were in the ER-/PR-/HER2+/- group which is not insignificant.

\section{Conflict of interests}

The author(s) declared no potential conflicts of interest with respect to the research, authorship, and/or publication of this article.

\section{Funding}

The author(s) disclosed receipt of the following financial support for the research, authorship, and/or publication of this article: This research was supported by project grant No. 943023595 of research deputy of Lorestan University.

\section{References}

AHREN, T. E., R. C. BIRD, A. E. BIRD, L. G. WOLFE (1996): Expression of the oncogene c-erbB-2 in canine mammary cancers and tumor-derived cell lines. Am. J. Vet. Res. 57, 693-696.

BARDOU, V. J., G. ARPINO, R. M. ElledGe, C. K. OSBORNE, G. M. CLARK (2003): Progesterone receptor status significantly improves outcome prediction over estrogen receptor status alone for adjuvant endocrine therapy in two large breast cancer databases. J. Clin. Oncol. 21, 1973-1979.

DOI: 10.1200/JCO.2003.09.099

BAUER, K. R., M. BROWN, R. D. CRESS, C. A. PARISE, V. CAGGIANO (2007): Descriptive analysis of estrogen receptor (ER)-negative, progesterone receptor (PR)negative, and HER2-negative invasive breast cancer, the so-called triple-negative phenotype: a population-based study from the California cancer Registry. Cancer 109, 1721-1728.

DOI: $10.1002 /$ cncr.22618 
BERNEX, F., P. DE SEPULVEDA, C. KRESS, C. ELBAZ, C. DELOUIS, J. J. PANTHIER (1996): Spatial and temporal patterns of c-kit-expressing cells in WlacZ/+ and WlacZ/ WlacZ mouse embryos. Development. 122, 3023-3033.

CAO, Q. J., J. G. JONES, M. LI (2001): Expression of calretinin in human ovary, testis, and ovarian sex cordstromal tumors. Int. J. Gynecol. Pathol. 20, 346-352. DOI: 10.1097/00004347-200110000-00006

CHAN, M., M. C. CHANG, R. GONZALEZ, B. LATEGAN, E. DEL BARCO, F. VERA-BADILLO, P. QUESADA, R. GOLDSTEIN, I. CRUZ, A. OCANA, J. J. CRUZ, E. AMIR (2015): outcomes of estrogen receptor negative and progesterone receptor positive breast cancer. Plos One 10, (7), e0132449.

DOI: 10.1371/journal.pone.0132449

CHANG, C. C., M. H. TSAI, J. W. LIAO, J. P. CHAN, M. L. WONG, S. C. CHANG (2009): Evaluation of hormone receptor expression for use in predicting survival of female dogs with malignant mammary gland tumors. J. Am. Vet. Med. Assoc. 235, 391-395.

DOI: 10.2460/javma.235.4.391

CHANG, T. C., J. K. WANG, M. W. HUNG, C. H. CHIAO, L. C. TSAI, G. G. CHANG (1994): Regulation of the expression of alkaline phosphatase in a human breastcancer cell line. Biochem. J. 303, (pt 1), 199-205.

DOI: $10.1042 /$ bj3030199

CHUI, X., H. EGAMI, J. YAMASHITA, T. KURIZAKI, H. OHMACHI, S. YAMAMOTO, M. OGAWA (1996): Immunohistochemical expression of the c-kit protooncogene product in human malignant and non-malignant breast tissues. Br. J. Cancer 73, 1233-1236.

DOI: $10.1038 /$ bjc. 1996.236

CIAPUTA, R., M. NOWAK, J.A. MADEJ, D. PORADOWSKI, I. JANUS, P. DZIEGIEL, E. GORZYNSKA, M. KANDEFER-GOLA (2014) Inhibin-a, E-cadherin, calretinin and Ki-67 antigen in the immunohistochemical evaluation of canine and human testicular neoplasms. Folia. Histoch. Cytobiol 52, 326-334.

DOI: 10.5603/FHC.a2014.0036

COlditz, G. A., B. A. ROSNER, W. Y. CHEN, M. D. HOLMES, S. E. HANKINSON (2004): Risk factors for breast cancer according to estrogen and progesterone receptor status. J. Natl. Cancer. Inst. 96, 218-228. DOI: 10.1093/jnci/djh025

DE MAEYER, L., E. VAN LIMBERGEN, K. DE NYS, P. MOERMAN, N. POCHET, W. HENDRICKX, H. WILDIERS, R. PARIDAENS, A. SMEETS, M. R. CHRISTIAENS, I. VERGOTE, K. LEUNEN, F. AMANT, F. NEVEN (2008): Does Estrogen Receptor-Negative/ Progesterone Receptor-Positive Breast Carcinoma Exist? J. Clin. Oncol. 26, 335-336.

DOI: $10.1200 / J C O .2007 .14 .8411$

DI LORENZO, D., M. GIANNI, G. F. SAVOLDI, F. FERRARI, A. ALBERTINI, E. GARATTINI (1993): Progesterone induced expression of alkaline phosphatase is associated with a secretory phenotype in T47D breast cancer cells. Biochem. Biophys. Res. Commun. 192, 1066-1072. DOI: $10.1006 /$ bbrc.1993.1525
DI LORENZO, D., A. ALBERTINI, D. ZAVA (1991): Progestin regulation of alkaline phosphatase in the human breast cancer cell line T47. Cancer. Res. 51, 4470-4475. DOI: $10.1042 / b j 3030199$

FISHMAN, W. H. (1987): Oncotrophoblast gene expression: placental alkaline phosphatase. Adv. Cancer. Res. 48, 1-35. DOI: 10.1016/s0065-230x(08)60689-2

FRIEDMAN, L. S., P, MARTIN, S. J. MUNOZ (1996): Liver function tests and the objective evaluation of the patient with liver disease. In: Hepatology: a textbook of liver disease. (Zakim D, T. D. Boyer, Eds.) WB Saunders, Philadelphia, pp. 791-833.

FULTON, A., B. ARZI, B. MURPHY, D. K. NAYDAN, F. J. VERSTRAETE (2014): The expression of calretinin and cytokeratins in canine acanthomatous ameloblastoma and oralsquamouscellcarcinoma. Vet.Comp. Oncol.12,258-265. DOI: 10.1111/j. 1476-5829. 2012. 00356.

GERALDES, M., F. GARTNER, F. SCHMITT (2000): Immunohistochemical study of hormonal receptors and cell proliferation in normal canine mammary glands and spontaneous mammary tumors. Vet. Rec. 146, 403-406.

GOLDSCHMIDT, M., L. PENA, R. RASOTTO, V. ZAPULLI (2011): Classification and grading of canine mammary tumors. Vet. Pathol. 48, 117-131.

DOI: $10.1177 / 0300985810393258$

GUIL-LUNA, S., J. STENVANG, N. BRUNNER, R. SÁNCHEZ-CÉSPEDES, Y. MILLÁN, J. GÓMEZLAGUNA, J. MARTIN DE LAS MULAS (2014): Progesterone receptor isoform analysis by quantitative real-time polymerase chain reaction in formalin-fixed, paraffin-embedded canine mammary dysplasia and tumors. Vet. Pathol. 51, 895-902.

DOI: $10.1177 / 0300985813511127$

HARRIS, H. (1990): The human alkaline phosphatases: what we know and what we don't know. Clin. Chim. Acta. 186, 133-150.

DOI: 10.1016/0009-8981(90)90031-m

HEFTI, M. M., R. HU, N. W. KNOBLAUCH, L. C. COLLINS, B. HAIBE-KAINS, R. M. TAMIMI, A. H. BECK (2013): Estrogen receptor negative/progesterone receptor positive breast cancer is not a reproducible subtype. Breast. Cancer. Res. 15, R68.

DOI: $10.1186 /$ bcr3462

HENNESSY, B. T., A. M. GONZALEZ-ANGULO, K. STEMKE-HALE, M. Z GILCREASE, S. KRISHNAMURTHY, J. S LEE, J. FRIDLYAND, A. SAHIN, R. AGARWAL, C. JOY, W. LIU, D. STIVERS, K. BAGGERLY, M. CAREY, A. LLUCH, C. MONTEAGUDO, X. HE, V. WEIGMAN, C. FAN, J. PALAZZO, G. N HORTOBAGYI, L. K NOLDEN, N. J WANG,V. VALERO, J. W. GRAY, C. M. PEROU, G. B. MILLS (2009): Characterization of a naturally occurring breast cancer subset enriched in epithelial-to-mesenchymal transition and stem cell characteristics. Cancer Res. 69, 4116-4124.

DOI: 10.1158/0008-5472.CAN-08-3441

KOLTAI, Z., B, SZABÓ, J, JAKUS, P, VAJDOVICH (2018): Tyrosine kinase expression analyses in canine mammary gland tumours - A pilot study. Acta. Vet. Hung. 66, 294-308. DOI: $10.1556 / 004.2018 .027$ 
KUBO, K., S. MATSUYAMA, K. KATAYAMA, C. TSUTSUMI, K. YONEZAWA, T. SHIMADA, T. KOTANI, S. SAKUMA, F. OHASHI, Y. TAKAMORI (1998): Frequent expression of the c-kit proto-oncogene in canine malignant mammary tumor. J. Vet. Med. Sci. 60, 1335-1340.

DOI: $10.1292 /$ jvms.60.1335

LANGE, P. H., J. L. MILLAN, T. STIGBRAND, R. L. VESSELLA, E. RUOSLAHTI, W. H. FISHMAN (1982): Placental alkaline phosphatase as a tumor marker for seminoma. Cancer. Res. 42, 3244-3247.

LUGLI, A., Y. FORSTER, P. HAAS, A. NOCITO, C. BUCHER, H. BISSIG, M. MIRLACHER, M. STORZ, M. J. MIHATSCH, G. SAUTER (2003): Calretinin expression in human normal and neoplastic tissues: a tissue microarray analysis on 5233 tissue samples. Hum. Pathol. 34, 9941000.

DOI: $10.1053 / \mathrm{s} 0046-8177(03) 00339-3$

MAFFINI, M. V., A. M. SOTO, C. SONNENSCHEIN, N. PAPADOPOULOS, T. C. THEOHARIDES (2008): Lack of c-Kit receptor promotes mammary tumors in $\mathrm{N}$-nitrosomethylurea-treated Ws/Ws rats. Cancer. Cell. Int. 8,5 .

DOI: $10.1186 / 1475-2867-8-5$.

MAHZOUNI, P., M. JAFARI (2012): The study of CD117 expression in glial tumors and its relationship with the tumor-type and grade. J. Res. Med. Sci. 17, 159-163.

MARTIN DE LAS MULAS, J., Y. MILLAN, R. DIOS (2005): A prospective analysis of immunohistochemically determined estrogen receptor alpha and progesterone receptor expression and host and tumor factors as predictors of disease-free period in mammary tumors of the dog. Vet. Pathol. 42, 200-212.

DOI: $10.1354 /$ vp.42-2-200

MCDICKEN, I. W., G. H. STAMP, P. J. MCLAUGHLIN, P. M. JOHNSON (1983): Expression of human placentaltype alkaline phosphatase in primary breast cancer. Int. J. Cancer. 15, 205-209.

DOI: $10.1002 /$ ijc.2910320211.

MILlANTA, F., M. CALANDRELlA, G. BARI, M. NICCOLINI, I, VANNOZZI, A. POLI (2005): Comparison of steroid receptor expression in normal, dysplastic, and neoplastic canine and feline mammary tissues. Res. Vet. Sci. 79, 225-232.

DOI: $10.1016 /$ j.rvsc.2005.02.002

MILNE, E. M. (1985): The diagnostic value of alkaline phosphatase in canine medicine: a review. J. Small. Anim. Prac. 26, 267-278.

DOI: $10.1111 / \mathrm{j} .1748-5827.1985 . t b 02111$

MOSSNER, E., G. PFLEIDERER, K. D. DITTEL (1984): Placental alkaline phosphatase in tumor tissue and serum. J. Clin. Chem. Clin. Biochem. 22, 467-471.

DOI: $10.1515 / \mathrm{cclm} .1984 .22 .7 .467$

MOUSER, P., M. A. MILlER, E. ANTUOFERMO, S. S. BADVE, S. I. MOHAMMED (2010): Prevalence and classification of spontaneous mammary intraepithelial lesion in dogs without clinical mammary disease. Vet. Pathol. 47, 275-284.

DOI: $10.1177 / 0300985809358603$
NADJI, M., C. GOMEZ-FERNANDEZ, P. GANJEI-AZAR, A. R. MORALES (2005): Immunohistochemistry of estrogen and progesterone receptors reconsidered: experience with 5,993 breast cancers. Am J. Clin. Pathol. 123, 21-27.

DOI: $10.1309 / 4$ wv79n2ghj3x1841

NATALI, P. G., M. R. NICOTRA, I. SURES, M. MOTTOLESE, C. BOTTI., A. ULLRICH (1992): Breast cancer is associated with loss of the c-kit oncogene product. Int. J. Cancer. 52, 713-717.

NEUSCHHWANDER-TETRI, B. A. (1995): Common blood tests for liver disease. Which ones are most useful? Post. Grad. Med. J. 98, 49-56.

DOI: $10.1002 / \mathrm{ijc} .2910520508$

ONITIL, A. A., J. M. ENGEL, R. T. GREENLEE, B. N. MUKESH (2009): Breast cancer subtypes based on ER/ PR and HER2 expression: comparison of clinicopathologic features and survival. Clin. Med. Res. 7, 4-13.

DOI: $10.3121 / \mathrm{cmr}$. 2009. 825.

ORDAS, J., Y. MILLAN, R. DIOS, C. REYMUNDO, J. M. DE LAS MULAS (2007): Proto-oncogen HER2 in normal, dysplastic and tumorous feline mammary glands: an immunohistochemical and chromogenic in situ hybridization study. BMC. Cancer 7, 179.

DOI: 10.1186/1471-2407-7-179.

PARISE, C., V. CAGGIANO (2014): Breast cancer survival defined by the ER/PR/HER2 subtypes and a surrogate classification according to tumor grade and immunohistochemical biomarkers J. Cancer. Epidemiol 2014, Article ID 469251,1-11.

DOI: $10.1155 / 2014 / 469251$

PENA, L., A. GAMA, M. H. GOLDSCHMIDT, J. ABADIE, C. BENAZZI, M. CASTAGNARO, L. DÍEZ, F. GÄRTNER, E. HELLMÉN, M. KIUPEL, Y. MILLÁN, M. A. MILLER, F. NGUYEN, A. POLI, G. SARLI, V. ZAPPULLI, J. MARTN DE LAS MULAS (2014): Canine mammary tumors: A review and consensus of standard guidelines on epithelial and myoepithelial phenotype markers, HER2, and hormone receptor assessment using immunohistochemistry. Vet. Pathol. 51, 127-145. DOI: $10.1177 / 0300985813509388$

POWELL, G., H. ROCHE, W. R. ROCHE (2011): Expression of calretinin by breast carcinoma and the potential for misdiagnosis of mesothelioma. Histopathol. 59, 950-956. DOI: $10.1111 /$ j.1365-2559.2011.04031.

RADI, Z. A., D. L. MILLER (2005): Immunohistochemical expression of calretinin in canine testicular tumours and normal canine testicular tissue. Res. Vet. Sci. 79, 125-129. DOI: 10.1016/j.rvsc.2004.11.016

REGAN, J. L., H. KENDRICK, F. A. MAGNAY, V. VAFAIZADEH, B. GRONER, M. J. SMALLEY (2012): c-Kit is required for growth and survival of the cells of origin of Brcal-mutation-associated breast cancer. Oncogene. 31, 869-883.

DOI: $10.1038 /$ onc.2011.289

REICHLING, J.J., M.M.KAPLAN(1988): Clinicaluse of serum enzymes in liver diseases. Dig. Dis. Sci. 33, 1601-1614.

RICKETTS, D., L. TURNBULL, G. RYALL, R. BAKHSHI, N. S. RAWSON, J. C. GAZET, C. NOLAN, R. C. COOMBES (1991): Estrogen and Progesterone receptors in normal female breast. Cancer. Res. 51, 1817-1822. 
ROGERS, J. H. (1987): Calretinin: a gene for a novel calciumbinding protein expressed principally in neurons. J. Cell. Biol. 105, 1343-1353.

DOI: $10.1083 /$ jcb.105.3.1343

RUNGSIPIPAT, A., S. TATEYAMA, R. YAMAGUCHI, K. UCHIDA, N. MIYOSHI, T. HAYASHI (1999): Immunohistochemical analysis of c-yes and c-erbB-2 oncogene products and p53 tumor suppressor protein in canine mammary tumors. J. Vet. Med. Sci. 61, 27-32.

DOI: $10.1292 /$ jvms.61.27

RUTTEMAN, G. R., W. MISDORP, M. A. BLANKENSTEIN, W. E. VAN DEN BROM (1988): Oestrogen (ER) and progestin receptors (PR) in mammary tissue of the female dog: different receptor profile in non-malignant and malignant states. Br. J. Cancer. 58, 594-599.

DOI: $10.1038 /$ bjc. 1988.266

SALVADOR, R. C. L., T. M. M. RAPOSO, C. E. FONSECAALVES, E. M. TERRA, G. R. VARALLO, R. LAUFERAMORIM (2013): Evaluation of c-KIT protein expression in canine mammary tumors. BMC. Proceed. 7, 63.

DOI: 10.1186/1753-6561-7-S2-P63

SAMOSZUK, M., M. A. CORWIN (2003): Acceleration of tumor growth and peri-tumoral blood clotting by imatinib mesylate (Gleevec). Int. J. Cancer. 106, 647-652.

DOI: $10.1002 /$ ijc. 11282

SHEN, T., M. BRANDWEIN-GENSLER, O. HAMEED, G. P. SIEGAL, S. WEI (2015): Characterization of estrogen receptor-negative/progesterone receptor-positive breast cancer. Hum. Pathol. 46, 1776-1784.

DOI: 10.1016/j.humpath.2015.07.019
STIGBRAND, T., P. A. HOLMGREN, A. JEPPSSON, M. G. DAMBER, B. VON SCHOULTZ (1985): On the value of placental alkaline phosphatase as a marker for gynecological malignancy. Acta Obstet. Gynecol. Scand. 64, 99-103.

DOI: $10.3109 / 00016348509154699$

TALIANO, R. J., S. LU, K. SINGH, S. MANGRAY, R. TAVARES, L. NOBLE, M. B. RESNICK, E. YAKIREVICH (2013): Calretinin expression in highgrade invasive ductal carcinoma of the breast is associated with basal-like subtype and unfavorable prognosis. Hum. Pathol. 44, 2743-2750.

DOI: 10.1016/j.humpath.013.07.021

ULIVI, P., W. ZOLI, L. MEDRI, D. AMADORI, L. SARAGONI, F. BARBANTI, D. CALISTRI, R. SILVESTRINI (2004): c-Kit and SCF expression in normal and tumor breast tissue. Breast Cancer. Res. Treat. $83,33-42$.

DOI: 10.1023/B:BREA.0000010694.35023.9e

ZHANG, Y., K. A. TOY, C. G. KLEER (2012): Metaplastic breast carcinomas are enriched in markers of tumorinitiating cells and epithelial to mesenchymal transition. Mod. Pathol. 25, 178-184.

DOI: $10.1038 /$ modpathol.2011.167

ZAMANI-AHMADMAHMUDI, M., S. M. NASSIRI, R. RAHBARGHAZI (2014): Serological proteome analysis of dogs with breast cancer unveils common serum biomarkers with human counterparts. Electrophoresis 35, 901-910.

DOI: $10.1002 /$ elps.201300461

Received: 16 December 2018

Accepted: 30 June 2020

\section{DEZFOULIAN, O., H. AKBAREIN, S. JAMSHIDI, H. GOLSHAHI, H. M. LAKOORAJ, L. HAGHIGHI: Izražajnost kalretinina kao biomarkera rizika za metastatski karcinom mliječne žlijezde u pasa. Vet. arhiv 90, 453-466, 2020.}

\section{SAŽETAK}

Maligni tumori dojke najčešći su tumori u ljudi i povezani su s lošom prognozom. Da bi se testirali novi dijagnostički postupci i terapijske procedure u ljudi, potreban je prikladan životinjski model tumorogeneze mliječne žlijezde. Psi su potencijalno dobar model zbog spontanog razvoja ovakvih tumora. U ovom su istraživanju, s ciljem stupnjevanja malignosti, međusobno uspoređena tri imunomarkera, kalretinin, c-Kit (CD117) i placentalna alkalna fosfataza (Plap), a zatim su isti uspoređeni i s estrogenskim, progesteronskim te HER2 (trostrukim) markerima. Povećanje izražajnosti kalretinina i placentalne alkalne fosfataze, bez imunoreakcije na c-Kit u neoplastičnim stanicama povezano je s visokim stupnjem malignosti. Od 50 tumora, 31 je metastazirao, od kojih je 29 (93,5\%) bilo umjereno do izrazito pozitivno na kalretinin $(\mathrm{P}<0,05)$. Doduše, rezultati za c-Ki ti Plap+ nisu bili ponovljivi. Zaključujemo da bi kalretinin mogao poslužiti kao biomarker u dijagnostici metatstatskog raka dojke.

Ključne riječi: biomarker; tumor mliječne žlijezde u pasa; kalretinin; c-kit; placentalna alkalna fosfataza 